DAIANA GÂRDAN

\title{
DISTANT READING THE SOCIAL NOVEL IN ROMANIA. THEORETICAL AND TAXONOMICAL CHALLENGES ${ }^{1}$
}

As a critical construct, "the social novel" fits like a glove the literary historians and critics of early $20^{\text {th }}$ century Romania. As realist novels were already praised and canonized in the international literary field, the autochthonous cultural ideologists active at the time were in search of a literary formula that shared an affinity with their legitimizing programmes. That is, I think, the key factor that makes pinpointing the introduction and first definitions of this particular subgenre (a technical term that has retrospective application, of course) in the Romanian critical discourse an almost impossible task. Populist propaganda journals such as Sămănătorul [The Sower] or Viața Românească [The Romanian Life] seem to register the highest frequency in using this label. A rather odd fact surfaces, however, when looking closer at these occurrences: the social novel is an applied label rather than an issue discussed or theorized, as if its very nature were selfexplanatory. In 1910, while reviewing Dumitru C. Moruzi's novel Înstrăinații [The Estranged], Nicolae Iorga provided one of the most articulate comments regarding the social novel, maybe the one that hits closest to base when searching for a definition. In this sense, Iorga states the following:

\begin{abstract}
About ten years ago, the world was won over by the novelty of one shining literary form, by the observational truth enclosed in it, by the interest in human typologies that either appeared for the first time or have taken back their rightful place after being overwhelmed by imitations of Paris latest fashions [...]. Ever since, people have demanded a literature that works like a symbol, a watchword, a battle cry, a true awakening of national energies, a solution for the emerging moral, political and social crises. [...] They [the young writers] can learn one important thing from Maupassant's techniques: that a novel as per today's standards must be the product of either a vast experience, or of an honest study of our national, social, and moral realities ${ }^{2}$.
\end{abstract}

Therefore, a social novel is, for Iorga, a social instrument: honest (in terms of current social contexts), but aspirational; observational, but instructive. In this paper, I aim to retrace some of the historical negotiations of this subgenre as they can be found in foreign theoretical discussions, as well as its many uses in

\footnotetext{
${ }^{1}$ This article is a revised and extended version of a paper presented at the International Conference „Zilele Sextil Puşcariu” (12-13 September 2019) and published, in Romanian, in the conference proceedings (Caietele Sextil Puşcariu, 2019, 4, pp. 418-427). This is the first internationally available rendition.

${ }^{2}$ Nicolae Iorga, "În legătură cu un roman social" ["Regarding a Social Novel”], Neamul Românesc Literar, 2, 1910, 31, p. 1. All translations are mine, unless otherwise indicated.
} 
Romanian literature and criticism in the first half of the $20^{\text {th }}$ century. My objective is not only to reveal the many contradictions and problematic aspects that surround this subgenre, but also to provide a more functional definition that may be of use for quantitative and digital approaches dedicated to this particular period.

\section{International Use}

My first attempt at investigating the genealogy of this concept is based on the premise that the presence of the social novel as a novelistic subgenre or typology in Romanian pre- and interwar criticism is due to foreign import, most likely from the French cultural space ${ }^{3}$. In French criticism, the social novel attracted the literary historians' attention especially at the dawn of the $20^{\text {th }}$ century. In the first decade, two volumes entirely dedicated to this particular novelistic formula make their entrance on the publishing market.

The first, entitled Le roman social en Anglettere (1830-1850), belongs to Louis Cazamian. Published in 1903, reedited, and extended in 1904, this ample volume not only assigned this subgenre to a specific historical and spatial context (Victorian England), but also aimed to delineate thoroughly between different types of social novel, consequently delving into internal sub-categorization of this already well established subgenre. Following a proposed periodization, the social novel registered three phases, each one of them presenting internal differentiations while the main objective remained the same, that of metabolizing and acting towards the impact of industrialization on society. The first phase (1830-1850) and the most carefully analysed - is an exalted one, with a revolutionary tonality:

Le roman social est animé d'un esprit nouveau. Le second système de forces, dirige vers la correction de l'individualisme, apparait de plus en plus nettement à côte du premier; en même temps, un mouvement sentimental de la conscience publique se cristallise dans la notion d'une solidarité sociale. Le roman de Dickens et de Kingsley en est à la fois l'un des effets et l'une des causes ${ }^{4}$.

Following the socio-political conflicts and tensions, the social novel written between 1850 and 1870 - the second phase, as Cazamian identifies it - leaves behind the enthusiastic revolutionary emotional tone and replaces it with a sceptical one: people have started to lose both faith and aggressiveness in demanding social change and started relying on science. Analysing Charles Dickens's work, the author he finds the most relevant literary phenomenon to shape the youth's social consciousness and inflating their civil spirit, the French

\footnotetext{
3 This analysis reiterates elements from Andrei Terian, Daiana Gârdan, Cosmin Borza, David Morariu, Dragoş Varga, "Genurile romanului românesc în secolul al XIX-lea. O analiză cantitativă" ["Genres of the Romanian Novel from the $19^{\text {th }}$ Century. A Quantitative Approach"], Transilvania, 10, 2019, pp. 17-28.

${ }^{4}$ Louis Cazamian, Le roman social en Angleterre (1830-1850), Paris, Société nouvelle de librairie et d'édition, 1903, p. 111.
} 
scholar delves into an evolutionary approach to the literary object. While commenting on "the social scope of Dickens' novels", the French author notes the following:

La valeur sociale de son œuvre nous apparait donc comme psychologique. Elle réside dans les émotions que l'auteur éprouve et suscite, à propos de l'inégalité humaine connue et décrite dans sa généralité. Aux problèmes spéciaux de la société industrielle, tels qu'ils se posaient entre 1830 et 1850 , ses romans ne fournissent pas de réponse directe. Son influence n'en est pas moins réelle, mais c'est sur les âmes qu'elle s'exerce. Elle est à la fois effet et cause d'une réaction profonde du tempérament national : elle accentue la révolte du sentimentalisme chrétien contre la sécheresse utilitaire ${ }^{5}$.

After carrying out his social reading of Dickens, Cazamian further investigates Kingsley's, Disraeli's and Gaskell's works with an evolutionary-orientated eye ("Nous avons vu le sentimentalisme social naitre, se nourrir, et aboutir au

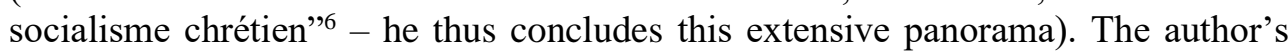
analysis of the so-called third phase of the social novel is absent, however. Identified around 1880, there is little to no clear information on its nature, other than the fact that it is more "pessimistic" than the previous two. Cazamian's study engages much more in political and socio-economic aspects of the targeted time frame than in the hermeneutics of the social novel. In conclusion, the social novel is, according to Louis Cazamian, a social instrument - an object that can function both as a trigger or as a result, or, in the author's own words, both as a cause and as an effect.

The second critical text concerning the social novel belongs to Jean CharlesBrun, another French scholar interested, at the turn of the century, in defining the subgenre. Charles-Brun knows Cazamian's works and engages in an extended dialogue with Cazamian in his own volume. Writing Le roman social en France au XIX siècle in 1910, Charles-Brun transplants Cazamian's critical assessments on the English novel into the French literary space. For this second French scholar, the social novel is divided into two subcategories: roman social and roman à thése. Although this separation may seem functional, Charles-Brun's analysis is a constant (re)negotiation of the relationship between literature and the social phenomena. While Cazamian seems to depart from a well-grounded premise regarding the very legitimacy of a social novel (and social literature in general), Charles-Brun tends to question the core issues: inner contradictions, its flexible uses, the superposition of social and moral literature - an issue I will address later in this article -, and finally, the very slippery nature of this label. In this sense, quite early in his demonstration he notes the following:

\footnotetext{
${ }^{5}$ Ibidem, p. 313.

${ }^{6}$ Ibidem, p. 540.
} 
On peut ne pas savoir avec exactitude ce qu'est une œuvre sociale, tant ce terme imprécise cache de notions diverses. On ne peut ignorer, du moins, l'extraordinaire floraison des œuvres qui se parent de ce titre. Le mot semble magique. Un article de revue, une exposition artistique, une méchante représentation de plein air, ont une «portée sociale ». Le moindre geste de nos esthètes s'inscrit en valeur. Et, pour le roman, c'est, sans doute le genre ou la prétention sociale s'affiche avec le plus de frénésie ${ }^{7}$.

One should keep in mind that for the given period, the novel was rather an underdog among literary genres ${ }^{8}$. It is not at all surprising that the novelistic genre is in some ways the genre of and for the people, a genre we would now call, following Bakhtin's writings, democratic - thus, a social genre. Charles-Brun himself feels the need to motivate his choice. He responds to the question of why a discussion of the novel in a paradigm dominated by theatre as the star-genre is worth having with the following argument: "la thèse du philosophe, la spéculation du théoricien ont besoin, pour pénétrer la masse, d'une transcription plus aisément accessible. Entre eux et le gros du public, le romancier sert d'intermédiaire: il décante, il simplifie, il grossit, il vulgarise" ". Starting from such a premise, it seems that, no matter what subject a novel may have, it has an inherent social purpose. From a metacritical point of view, it would appear that Charles-Brun divides the novel - the genre itself, the whole production - into roman social and roman à thése, rather than proposing two subgenres localized in a broader field. A "social novel" is, as per the author's demonstration, the novel that has to do with "social pressure", while a "thesis novel" is a novel that has to do with "social preoccupation". The latter is actually the one that we tend to label as a social novel now: the instrument/ object of instruction/ literature with an active role in a given socio-political background.

The type Charles-Brun identifies as social novel, however, is the problematic one. It depicts, the French scholar states, a world where the characters' (especially the protagonist's) thoughts and actions are driven by the "social milieu". In other words, he identifies the realists. At least, that would be the first conclusion. Nevertheless, if we look at, let us say, Proustian novels, this statement could still be viable. This is exactly the kind of vicious circle that this particular label is likely to fall into: everything is a social novel and nothing is a social novel - the very reason why most approaches to genre theory avoid this label.

Although both are indebted to the same cultural space - France - and build on more or less the same premises, the two scholars reach very different conclusions.

\footnotetext{
${ }^{7}$ Jean Charles-Brun, Le roman social en France au XIX siècle, Paris, V. Giard \& E. Brière LibrairesÉditeurs, 1910, p. 51.

${ }^{8}$ I have tried to briefly retrace this evolution, from a "minor" literary genre to a canonical one, in a recent article: Daiana Gârdan, “One Theory's Underdog Is Another Theory's Treasure: The Novelistic Genre in Different Regimes of Relevance", Transilvania, 2020, 5, pp. 15-19.

${ }^{9}$ Jean Charles-Brun, Le roman social en France, p. 46.
} 
However, something in particular stands out: both Cazamian and Charles-Brun understand the social novel more as an instructive object than as a novelistic form.

The social novel seems to have no special architecture, no particular device, and no outstanding feature. It can penetrate almost every setting: it can be a love story, a rural novel, a bourgeois or family drama. So how can we surmount such a paradox? Before trying to answer this difficult question, I will retrace the national ramifications of this label.

\section{National Use}

The import of this novelistic typology from the French space in Romania seems plausible due to two logistic realities. One: the French language was the prevalent foreign language Romanian men of letters not only read, but also borrowed from in their own academic writing. Two: as I demonstrated on earlier occasions ${ }^{10}$ in quantitative form, Romanian modernity translated and discussed French novels more than those of any other national literature - including our own. While there is little to no reference to these two particular French scholars or their volumes, it does not seem far-fetched to suspect that this label still entered the Romanian literary circuit after making its way into the French one first and then being borrowed from authors and critics that had a steady presence in the Romanian cultural space. Direct contacts remain, however, impossible to trace.

For the "traditionalists"11, the social novel usually meant what Nicolae Iorga synthesized in the paragraphs I quoted at the beginning of this article. A distant reading of the periodicals in which populists like Ibrăileanu or nationalists like Iorga wrote (an endeavour made possible through the Bibliography of the Relations between Romanian Literature and Foreign Literatures in Periodicals ${ }^{12}$ and by digitized versions of some of these periodicals ${ }^{13}$ ), one can notice that the social novel was rather an ideological construct - in the sense of a desirable instructive

\footnotetext{
${ }^{10}$ Daiana Gârdan, "The Great (Female) Unread. Romanian Women Novelists in the First Half of the Twentieth Century: A Quantitative Approach", Metacritic Journal for Comparative Studies and Theory, 4, 2018, 1, pp. 109-124.

${ }^{11}$ This label is usually used to denominate the populist and nationalist camps, like the ones active in and around periodicals like Viața Românească [The Romanian Life] or Sămănătorul [The Sower]. For terminological clarifications, see Cosmin Borza, "Translating against Colonization. Romanian Populists' Plea for Peripheral Literatures (1890-1916)", in Maria Sass, Ștefan Baghiu, Vlad Pojoga (eds.), The Culture of Translation in Romania, Berlin, Peter Lang, 2018, pp. 31-43.

${ }^{12}$ Luminița Beiu-Paladi et alii, Bibliografia relațiilor literaturii române cu literaturile străine în periodice (1859-1918) [The Bibliography of the Relations of Romanian Literature with Foreign Literatures in Periodicals (1859-1918)], vol I-III, București, Editura Academiei RSR, 1980-1985 and Ana-Maria Brezuleanu et alii, Bibliografia relațiilor literaturii române cu literaturile străine în periodice (1919-1944) [The Bibliography of the Relations of Romanian Literature with Foreign Literatures in Periodicals (1919-1944)], vol. I-X, București, Saeculum, 1997-2009.

13 See, for instance, Viața Românească, 1906-1939 here: http://dspace.bcuiasi.ro/handle/123456789/657.
} 
object - that they promoted. Tolstoy, Dostoyevsky, Gorki, Balzac, Maupassant, Flaubert, Zola, Hugo, even Henry Sienkiewicz were writers of social novels - all of their productions canonical models, all of these authors actively shaping European realism. In an article later included in Note şi impresii [Notes and Impressions], G. Ibrăileanu glorifies Tolstoy's novel by saying that it is "the most powerful novel of our times, due to its social, evangelical, political, and sometimes revolutionary nature"14. As I have already mentioned, Romanian scholars did not engage in formulating a rigorous definition of what the social novel meant for them. It was a notion somehow taken for granted. The label seems to be such an autonomous notion in their texts that they used it mostly as some kind of certificate of high achievement. For "traditionalists", a social novel was not a subgenre, it was a literary quality all novels should aspire to possess.

For the "modernists", the social novel was something closer to a subgenre, but nonetheless fluid in its features. In 1925, G. Silviu, a constant presence at E. Lovinescu famous literary circle Sburătorul, writes a review for N. Davidescu's novel Conservator \& $\mathrm{Cia}$ in the modernist journal Dimineața. He makes the following general observations:

The contemporary novel - the social novel - can only be the image of the burlesque society that the bloody events of the past few years have left us with. The man of our times does not think - does not feel - does not have the same emotional response to things as the man that lived eleven years ago. This truth is so natural yet so hard to understand, and that is why so many tragedies - big or small - are born [...] D. N. Davidescu is - obviously - going to make a part of our critics unhappy. He does no longer speak of romantic lovers or their pink letters. D. N. Davidescu has cut, with a firm hand nonetheless, a slice of life from the first years after the war. He forged it as if it had been an odd piece of ore, he examined in a contemporary fashion [...] At any rate, his novel [Conservator \& $\left.C^{i a}\right]$ is a textbook social novel, written with the nerve and talent of a true artist ${ }^{15}$.

As for most of the modernists that attended the same social and literary circles as he did, George Silviu understood the social novel in a radically different way than his "traditionalist" counterparts. For young writers entranced by fashionable, modern aspirations and who happened to suffer the traumatic experience of war, social literature embodies an almost therapeutic process, or at least it should do so. The world has changed forever and even though Romanian novelistic production does not have a "Lost generation" novel, young modernist writers expressed the same needs. Thus, the distance between the social novel advertised by the nationalist parties and the social novel promoted by Lovinescu and by his circle is the distance between Anna Karenina and The Great Gatsby. Nevertheless, as per Charles-Brun's definition, a social novel is a novel that has to do with social

\footnotetext{
${ }^{14}$ G. Ibrăileanu, Note și impresii [Notes and Impressions], Iași, Viața Românească, 1920, p. 139.

${ }^{15}$ G. Silviu, "Romanul social de după război" ["The Social Novel after the War"], Dimineața, 21, 1925, 6541, p. 3.
} 
pressure and the impact of historical events on the social behaviour and psychology of the characters. Looking at it from this point, Tolstoy and Fitzgerald do not seem so different; after all, they both metabolized the way people react while facing social pressure and tried to make an instructive point out of doing so. The modernist party, however, seem to be closer to pinning down a specific formula for the social novel. While the "traditionalist" has talked about an instructive spirit, the modernist is targeting a certain topic - the aftermath of the war.

We are now left with the same series of contradictions we started out with in the first place. The two French scholars I have chosen for this demonstration either superimposed social literature and the literature of manners, or chose to display an array of novels that engage in social topics and politics so vast and different in their narrative and thematic particularities that it has made it impossible to find what can or cannot be a social novel. The Romanian space provided a mere confirmation of these contradictions. So how can the social novel be a viable subgenre for distantreading the modern Romanian novel?

\section{The Current State}

Two "textbook definitions" for the social novel are the subject of critical consensus. The first is the following: "une œuvre littéraire qui dénonce, généralement par le biais d'une fiction réaliste, des problèmes sociaux et leurs effets sur les personnes ou groupes qui en sont victimes, issus des classes populaires" (Grande Encyclopédie). The second one is "a work of fiction in which a prevailing social problem, such as gender, race, or class prejudice, is dramatized through its effect on the characters of a novel" (Encyclopaedia Britannica). While these dictionary definitions may prove functional in a hermeneutical tradition, they fail to work with distant reading endeavours.

The primary instrument used for the distant reading of the Romanian novel remains Dicționarul cronologic al romanului românesc de la origini până la 1989 [Chronological Dictionary of the Romanian Novel from Its Origins to 1989] (DCRR), a dictionary that has indexed numerous novels as social ones. This lexicographic tool, however, was not designed with quantitative studies in mind. Although this instrument gives a comprehensive bird's-eye-view of the novelistic production in Romania since its very origins, indexing most useful data about each novel, it lacks the generation of a relevant thematic categorization of the novel. Every entry contains the whole bibliographical reference pertaining to the novel (author, full title, publishing house or periodical issue, year) completed by a set of critical references and a sometimes very short, sometimes very detailed, description of the novel's subject, setting, characters, themes etc. In a genre-centric approach, the subgenre of each novel can only be extrapolated from the information available in the narrative section. This segment however is rather heterogeneous. While canonical novels receive more attention, minor novels are treated superficially in what concerns the plot or formal aspects. While some subgenres seem to be more 
stable (like romance/ sentimental novels or crime fiction), others seem to be lost in translation. This is the case of the social novel. Approximately one hundred novels are indexed as social in DCRR between 1845 (origins) and 1939. Forty-seven are to be found in the inter-war period. Fourteen other novels are indexed as novels "of social observation". Other fourteen have "social novel" in the title. Similar numbers, in the same time frame, are registered when searching for "novel of manners". The latter are also around a hundred in total, forty-nine in the inter-war period, eighteen indexed as "novels with moralistic intentions/aims" and fourteen containing the phrase "novel of manners" in their title. Sixteen other novels are indexed as "social novel of manners". From a distant reading perspective, the lack of coherence is easily noticeable.

Here are just a few simplified examples:

1. V. Urechia, Coliba Măriucăi [Măriuca's Cabin] (an imitation of Uncle Tom's Cabin) - a novel about slavery in Moldavia;

2. Constanța Dunca-Schiau, O familie din București. Iezuiții României $[A$ Family from Bucharest. Romania's Jesuits] - a family drama filled with sensational elements;

3. I. Fundescu, Scarlat. Roman original [Scarlat. An Original Novel] - a sensational novel set in a bourgeois décor;

4. G. Baronzi, Confidențele unui om de inimă [The Secrets of a Good Man] - a love story with melodramatic elements;

5. Eugenia de Reuss, Spre desrobire [Towards Emancipation] - a novel that militates for women's emancipation;

6. Ludovic Dauș, Dușmani ai neamului [Nation's Enemies] - a novel with nationalistic tendencies;

7. Mateiu Caragiale, Craii de Curtea-Veche [Gallants of the Old Court] - a Proustian novel

I have reproduced what I think is a representative selection that accommodates the main topics that the authors of DCRR considered worth labelling as social. The same paradox arises: almost every novel can be a social novel.

Where critical assessments fail, the authors may provide some answers. The following novels were meant to be written as social novels:

1. N. Rădulescu-Niger, Tribunul poporului. Roman social [The People's Tribune. A Social Novel] - a novel with nationalistic tendencies that presents a conflict between a schoolteacher and a politician;

2. Petru Vulcan, Armâna. Roman social din epoca renașterei poporului român la Pind [The Armenian Girl. A Social Novel of the Renaissance of Romanian's People of Pind] - a historical novel presenting a conflict between the Romanians and the Greeks.

3. N. Rădulescu-Niger, Măria sa Ogorul. Roman social [His Highness, the Land. A Social Novel] - a rural novel following the conflicts between peasant families. 
4. Petru Vulcan, Mizerabilii noștri. Mare roman social [Our Miserable. A Great Social Novel] - unconsulted.

5. Olimpia Teodoro, Iubire fatală. Roman social [Fatal Love. A Social Novel] - a tragic love story, aiming to be a feminist novel.

6. Olimpia Teodoro, Un proces pierdut. Roman social [A Lost Trial. A Social Novel] - a tragic love story, aiming to be a feminist novel.

7. F. R. Atila, Ion Negan. Roman social [Ion Negan. A Social Novel] - a confusing peroration about social change.

8. Dumitru Moruzzi, Pribegi în țară răpită. Roman social basarabean [Wanderers in a Lost Country. A Bessarabian Social Novel] - a historical novel, presenting political and ethnic conflicts in a rural setting.

9. Dumitru Moruzzi, Moartea lui Cain. Roman social [The Death of Cain. A Social Novel] - a historical novel, following political and ethnical conflicts in a rural setting.

10. Aida Vrioni, Rătăcire. Roman social - a biographical novel about a young Jewish girl, presenting ethnical conflicts and trying to make an instructive point about tolerance.

11. Ștefan Popescu, Răzbunarea. Roman social [The Revenge. A Social Novel] - a rural novel with sensational elements (love triangles, infidelity, revenge plots).

12. George Raicu-Delahuși, Suflete predestinate. Roman social cu mici spicuiri de actualitate [Fated Souls. A Social Novel with Contemporary Excerpts] a love story with sensational and melodramatic elements.

13. Petre C. Georgescu-Delafras, Micul sacrificiu. Roman social [The Small Sacrifice. A Social Novel] - set in Bucharest, it presents the conflicts arising in some Romanian trade unions as a direct consequence of the war.

14. Vasile Burlacu, Zorile trandafirii. Roman social [Rose-Coloured Daybreak. A Social Novel] - a love story set in a rural décor, with melodramatic elements.

The motivations behind these choices remain unknown and the spectrum of plots and settings is as heterogeneous as in the previous list of novels. Yet we can extrapolate, for the first time, a recurrent element: conflict - usually generated by race or class or gender or other type of social inequality. This list seems to be the closest to the dictionary definition of the social novel. Nevertheless, it still fails to generate a stable subgenre.

\section{A Desirable Candidate}

What, then, is a social novel? Moreover, what are its relations with the novel of manners? There are multiple occurrences where they are interchangeable, both as conceptual entities in theoretical inquiries and in terms of novelistic plots in the actual literary production, as shown by DCRR. Although their use in quantitative 
endeavours is a difficult task, it is not an impossible one. I will further advance two possibilities.

1. Judging by all the definitions briefly retraced in this article, the safest way to keep this label as a subgenre in quantitative analyses while targeting Romanian modernity is to follow the two most stable recurrences: realism - in terms of formula and the presence of a social conflict based on race, gender, or class inequalities, that is, in terms of plot.

2. Following the modernist way of understanding the social novel, the second possibility revolves around the following idea: in order to be a social novel, a novel must not only be built around a social or historical event (revolution, war, or any other traceable events like the changing of a political regime), but it must also register a socially recognizable conflict generated by such an event. Albeit this would be more functional in an extended research that targets literary corpuses beyond modernity and beyond the Romanian space, this application could be problematic due to its lack of formal imperative. A novel that delves into the aftermath of war in order to make sense of what traumatized humanity feels could be both Proustian and realist, it could focus on private spaces, like the family or couples or, au contraire, on communities or work environments. The selection would need a greater degree of subjective interpretation and it could overlap once again with other subgenres such as romance or rural novels.

My inquiry did not aim to be exhaustive or to propose categorical definitions; it aimed to be a small contribution to a dynamic process of renegotiations of literary and critical terminologies. There are numerous methodological artefacts in literary history that cannot fit into a quantitative inquiry. In the case of the social novel however, some clarifications can help not only to backtrack the regionalisation of certain critical concepts in a peripheral cultural space, but also to mark a new beginning for the adaptation of old terms to new uses.

\section{BIBLIOGRAPHY}

DCRR - Dicționarul cronologic al romanului românesc de la origini până la 1989 [Chronological Dictionary of the Romanian Novel from Its Origins to 1989], București, Editura Academiei Române, 2004.

BEIU-PALADI, Luminița et alii, Bibliografia relațiilor literaturii române cu literaturile străine în periodice (1859-1918) [The Bibliography of the Relations of Romanian Literature with Foreign Literatures in Periodicals (1859-1918)], vol. I-III, București, Editura Academiei RSR, 19801985.

BORZA, Cosmin, "Translating against Colonization. Romanian Populists' Plea for Peripheral Literatures (1890-1916)", in Maria Sass, Ștefan Baghiu, Vlad Pojoga (eds.), The Culture of Translation in Romania, Berlin, Peter Lang, 2018, pp. 31-43. 
BREZULEANU, Ana-Maria et alii, Bibliografia relațiilor literaturii române cu literaturile străine în periodice (1919-1944) [The Bibliography of the Relations of Romanian Literature with Foreign Literatures in Periodicals (1919-1944)], vol. I-X, București, Saeculum, 1997-2009.

CAZAMIAN, Louis, Le roman social en Angleterre (1830-1850), Paris, Société nouvelle de librairie et d'édition, 1903.

CHARLES-BRUN, Jean, Le roman social en France au XIX siecle, Paris, V. Giard \& E. Brière Libraires-Éditeurs, 1910.

GÂRDAN, Daiana, “One Theory's Underdog Is Another Theory's Treasure: The Novelistic Genre in Different Regimes of Relevance", Transilvania, 5, 2020, pp. 15-19.

GÂRDAN, Daiana, "The Great (Female) Unread. Romanian Women Novelists in the First Half of the Twentieth Century: A Quantitative Approach", Metacritic Journal for Comparative Studies and Theory, 2018, 4(1), pp. 109-124.

IBRĂILEANU, G., Note şi impresii [Notes and Impressions], Iași, Viaţa Românească, 1920.

IORGA, Nicolae, "În legătură cu un roman social" [ "Regarding a Social Novel"], Neamul Românesc Literar, 2, 1910, 31, p. 1.

SILVIU, George, "Romanul social de după război" ["The Social Novel after the War"], Dimineața, $21,1925,6541$, p. 3.

TERIAN, Andrei, GÂRDAN, Daiana, BORZA, Cosmin, MORARIU, David, VARGA, Dragoş, "Genurile romanului românesc în secolul al XIX-lea. O analiză cantitativă" ["Genres of the Romanian Novel in the 19th Century. A Quantitative Approach”], Transilvania, 2019, 10, pp. $17-28$.

\section{DISTANT READING THE SOCIAL NOVEL IN ROMANIA. THEORETICAL AND TAXONOMICAL CHALLENGES (Abstract)}

The most recent theoretical projects dedicated to comparative and literary studies challenge the very critical vocabulary that we have inherited from the more traditional theoretical discourses such as hermeneutics. Transnational studies, World Literature, quantitative and digital formalism are, at the moment, some of the most methodologically meticulous subdomains in contemporary research, striving to simplify the academic language in order to achieve scientific specialization. Following this general direction, the present article aims to re-evaluate one of the most frequently misrepresented novelistic subgenre that poses many difficulties to any quantitative approach. As a typology, the social novel has been invoked without ever being discussed theoretically. The purpose of this paper is to retrace the many uses and meanings of this typology in critical discourse and to propose the specialization of this subgenre for the sake of further quantitative and digital investigations.

Keywords: social novel, subgenre, genre theory, quantitative studies, digital formalism.

\section{CITIND DE LA DISTANTTA ROMANUL SOCIAL ÎN ROMÂNIA. PROVOCĂRI TEORETICE ȘI TAXONOMICE (Rezumat)}

Cele mai recente proiecte teoretice aparținând domeniului studiilor literare și comparatiste provoacă o revizitare a vocabularului critic moștenit de la demersurile hermeneutice, fenomenologice, sau postmoderniste. Studiile transnaționale, World Literature, formalismul 
digital și studiile cantitative reprezintă, la ora actuală, una dintre cele mai bine dotate metodologic subdomenii de cercetare a producției literare și artistice, concentrându-și eforturile, în speță, asupra simplificării limbajului academic, prin eliminarea încărcăturii metaforice, în virtutea unei specializări a discursului despre literatură. Răspunzând la acest apel, lucrarea de față are drept obiect de cercetare unul dintre subgenurile romanești care ridică numeroase dificultăți la orice intenție de panoramare cantitativă. Romanul social a fost instrumentat, ca tipologie, de cele mai multe ori în absența unei definiții. Intenția acestei lucrări este de a retrasa multiplele instrumentări și semnificații primite de această tipologie și de a propune o specializare a acestui subgen, funcțională în demersuri cantitative și digitale.

Cuvinte-cheie: roman social, subgen, teoria genurilor, studii cantitative, formalism digital. 